\title{
NEW OR LITTLE-KNOWN SPECIES OF WEST INDIAN “TIPULIDAE" (DIPTTRA) L. I.
}

\author{
By Charles P. Alexander \\ Massachusetts State College, Amherst, Massachusetts
}

A few interesting new species of crane-flies have been included in various lots of specimens sent to me for identification. The following sources are included: Puerto Rico, through Dr. William A. Hoffman; Cuba, through Professor Stephen C. Bruner and Mr. A. R. Otero; and the Bahamas, through Dr. John G. Myers. Through the friendly interest of the abovementioned entomologists, I have been privileged to retain the types of the species in my private collection of these flies.

Shannonomyia hoffmani sp. n.

General coloration gray, the praescutum and scutum dark brown; pleura brownish black, sparsely pruinose; wings creamyellow, sparsely variegated by dark brown areas; cell $R 3$ small, vein $R 2+3$ being ionger than $R 2+3+4$; cell 1 st $M 2$ elongate, closed; abdomen black.

Male.-Length about 5.3 - $5.5 \mathrm{~mm}$; wing 5- $5.2 \mathrm{~mm}$.

Rostrum and palpi dark brown. Antennae short; scape, pedicel and basal one or two flagellar segments light yellow, the remaining segments brownish black; verticils exceeding the segments in lengti. Head gray, the front and anterior vertex clearer and lighter gray.

Pronotum and lateral pretergites clear gray, the latter extending to the wing-root. Mesonotal praescutum and scutum almost uniformly dark brown, the median area of the former darker, the lateral portions more pruinose; scutellum uniformly blackened, sparsely pruinose; mediotergite gray pruinose. Pleura brownish black, sparsely pruinose. Halteres chiefly pale. Legs with the coxae brownish testaceous; trochanters obscure yellow; femora obscure brownish yellow, the tips weakly darkened; tibiae brown, the tips narrowly more darkened; tarsi black. Wings (Fig. 1) with the ground-color cream-yellow, 
sparsely variegated by dark brown areas, including spots at arculus; a virtually common area at origin of $R s, S c 2$ and tip of $S c 1$; series of spots along cord and outer end of cell 1st M2; small marginal darkenings at tips of all longitudinal veins excepting $R 5$, the largest at 2 nd $A$; veins yellow, darker in the infuscated areas. No macrotrichia on $\mathrm{Rs}$ or its anterior branch; $R 5$ with abundant trichia over its entire length. Venation: Sc short, $S c 1$ ending about opposite one-third to one-fourth length of $R s, S c 2$ about mid-distance between $R s$ and the tip of $S c 1$; $R 2$ about one-half shorter than $R 2+3+4 ; R 2+3$ longer than $R 2+3+4$; cell 1 st $M 2$ elongate, closed; $m$-cu close to fork of $M$.

Abdomen black, the hypopygium a trifle paler.

Habitat.- Puerto Rico.

Holotype, male, Luquillo National Forest, at light, September 8, 1935 (W. A. Hoffman). Paratopotype, male.

Associated at light with Shannonomyia leonardi Alex. and Erioptera (Mesocyphona) portoricensis Alex.

I take great pleasure in naming this distinct crane-fly in honor of my long-time friend, Dr. William A. Hoffman. The only close ally in the West Indian fauna is Shannonomyia leonardi, likewise from the Luquillo National Forest. The latter is readily told by the uniform pale yellow coloration of the thorax, together with the brownish yeliow abdomen. By my key to the Puerto Rican species of the genus (Journ. Dept. Agr. Puerto Rico, 26: 368; 1932), the species runs directly to leonardi.

\section{Teucholabis (Teucholabis) oteroi sp. n.}

General coloration yellow, variegated witk black; lateral praescutal stripes bent laterad to margin; knobs of halteres infuscated; femora yellow, each with a single, narrow, pale brown ring immediately before midlength; tibiae uniformly yellow; wings whitish subhyaline, with three pale brown fasciae, the last being the narrow wing-tip; cell 1 st $M 2$ closed; abdomen yellow, the basal/tergite black, the outer segments restrictedly variegated by brown/areas; the basal areas; male hypopygium with the margin of the basistyle produced into a thin, slightly blackened plate or flange; basistyle not produced at apex.

Male.- Length about 8.5 - $9 \mathrm{~mm}$.; wing 7 - $7.5 \mathrm{~mm}$. 
Rostrum, brown, obscure yellow above, slightly shorter than the remainder of head; palpi black. Antennal flagellum black, the scape yellow; pedicel brownish yellow; flagellar segments oval, with conspicuous verticils. Front and anterior vertex blackened, the posterior vertex and occiput yellow, the latter with an inconspicuous darkened triangle.

Pronotum obscure yellow, darker anteriorly above. Mesonotal praescutum yellow, with three black stripes, the median one paling to brown on anterior end, its posterior portion ending abruptly some distance before the suture, leaving a conspicuous yellow area behind it; lateral stripes with anterior ends continued outward to margin of sclerite, isolating a yellow area between them and the suture; median area of scutum pale yellow, the lobes extensively darkened; scutellum weakly darkened; mediotergite obscure brownish yellow. Pleura chiefly darkened, heavily light gray pruinose. Halteres with the stem yellow, the knob infuscated. Legs with the coxae and trochanters obscure yellow; femora yollow, unmarked except for a single, narrow, pale brown ring just before midlength of the segment; tibiae and basitarsi yellow, the outer tarsal segments black. Wings (Fig. 1. 2) whitish subhyaline, with three pale brown fasciae, the first lying before level of origin of $R s$, extending from vein $R$ to the posterior margin; second band chiefly beyond level of cord, extending from the darker brown stigma to the posterior margin, including all of cell 1st M2; third band including the narrow wing-tip; veins yellow, the costal field more brightly so; veins darkened where traversing brown areas. Venation: Sc1 ending opposite midlength of $R s$, the latter moderately arcuated; $R 2+$ $3+4$ a little shorter than the slightly oblique $R 2$; branches of $R s$ lying approximately paralle! to one another to margin, cell $R 2$ being nearly three times as extensive at border as is cell $R 4$; cell 1 st $M 2$ closed: $m$-cu shortly beyond fork of $M$.

First abdominal tergite black; outer segments yellow, very vaguely and restrictedly marked with darker, more extensively so on the sternites; hypopygium pale. Male hypopygium with the mesal edge of basistyle thin and weakly blackened, spine of basistyle long, slender, gently curved, the basal half pale and dilated; basistyle not or scarcely produced caudad at outer end. Outer dististyle a gently curved rod that terminates in a simple spinous point. 


\section{Habitat.- Cuba (Pinar del Rio).}

Holotype, male, Las Animas, Sierra Rangel, altitude 1,500 feet, Septcmber 4, 1934 (S. C. Bruner and A. R. Otero). Paratopotype, male.

I take great pleasure in dedicating this interesting species to Mr. A. R. Otero, to whom I am indebted for several interesting species of Cuban Tipulidae. The species is very different from the remaining regional species of the genus in the diagnostic features listed. The nearest ally is the Jamaican Teucholabis (Teucholabis) gowdeyi Alexander, which differs conspicuously in the open cell $M 2$ of the wings, the leg-pattern, and the structure of $t r_{2} e$ male hypopygium.

Teucholabis (Teucholabis) portoricana sp. n.

Closely allied to $T$. (T.) myersi Alexander, of Cuba and southern Florida (Journ, N. Y. Ent. Soc., 34: 228 - 229; 1926), differing chiefly in the structure of the male hypopygium.

Male.- Length about $5 \mathrm{~mm}$; wing $5.5 \mathrm{~mm}$.

Female.- Length about $5 \mathrm{~mm}$.; wing $5 \mathrm{~mm}$.

Male hypopygium with the apical spine of basistyle a straight pale rod, terminating in a short acute spine that lies in the same axis as the remainder of the rod. Outer dististyle pale throughout, slender, the spine on mesal margin small, suberect. Inner dististyle with the outer emargination shallow and much shorter than the basal one, the denticle separating them low and obtuse. Aedeagus with the apical point straight, pale throughout.

The male hypopygium of myersi has the apical spine of the basistyle large and conspicuous, the basal half dilated, the distal half abruptly narrowed into a long sinuous spine. Outer dististyle darkened throughout, the spine on mesal margin acute, subappressed. Outer dististyle elongate, the two emarginations subequal in size or the outer a trifle more extensive, the median denticle acute. Aedeagus with the apical point curved, blackened.

Habitat.- Puerto Rico.

Holotype, male, El Semille, Villalba, altitude 1,600 feet, at 
lighat, January 26, 1935 (W. A. Hoffman). Allotype, female, Paratopotype, sex?

The wing-venation is shown in Figure 3.

\section{Toxorhina (Toxorhina) distalis sp. n.}

General coloration gray, the praescutum with three brown stripes; femora brownish yellow, the tips weakly darkened; tibiae brownish yellow, the tips narrowly brownish black; wings with macrotrichia of veins very sparse; $R s$ unusually long, exceeding in length vein $R 5$, due to the position of $r-m$ close to outer end of the long cell $1 s t$ M2; $m$-cu about two- thirds its length beyond the fork of $M$.

Female.- Length, excluding rostrum, $8 \mathrm{~mm}$; wing 5.5 $\mathrm{mm}$.

Rostrum broken beyond the base, which is dark brown. Antennae with basal segments dark bnown; outer flagellar segments broken. Head gray.

Cervical region dark brown. Mesonotum light gray, the praescutum with three brown stripes, the laterals somewhat less distinct; posterior interspaces weakly infuscated; centers of scutal lobes darkened; scutellum and mediotergite clear light gray. Pleura and extreme lateral margin of praescutum light gray, the ventral sternopleurite somewhat darkened. Halteres pale. Legs with the coxae weakly infuscated; trochanters yellowish testaceous; femora brownish yellow, the tips weakly darkened; tibiae obscure brownish black; tarsi brown. Wings (Fig. 4) with a grayish tinge, the pearcular region light yellow; veins brown. Macrotrichia of veins very sparse, in type with a single trichium near outer fourth of $R s$; four or five scattered along $R 5$; an equal number near outer end of cell 1 st M2 Venation: $R_{\mathrm{S}}$ unusually long, exceeding $R 5$, due to the position of $r-m$ far distad, close to outer end of cell 1 st $M 2$; cell 1 st $M 2$ present, elongate, exceeding cell 2 nd $M 2 ; r-m$ lying immediately before $m$; $m$-cu about two-thirds its length beyond the fork of $M$.

Abdominal tergites brown, the caudal and lateral borders, together with a more or less distinct crossband at midlength of the segments restrictedly darker. 
Habitat.- Bahamas.

Holotype, female, New Providence, May 1932 (J. G. Myers) ; Colector's No. 2557.

Toxorhina (Toxorhina) distalis is very different from all other regional species in the distal position of crossveins $r-m$ and $m-c u$, together with the unusually long cell $1 s t M 2$.
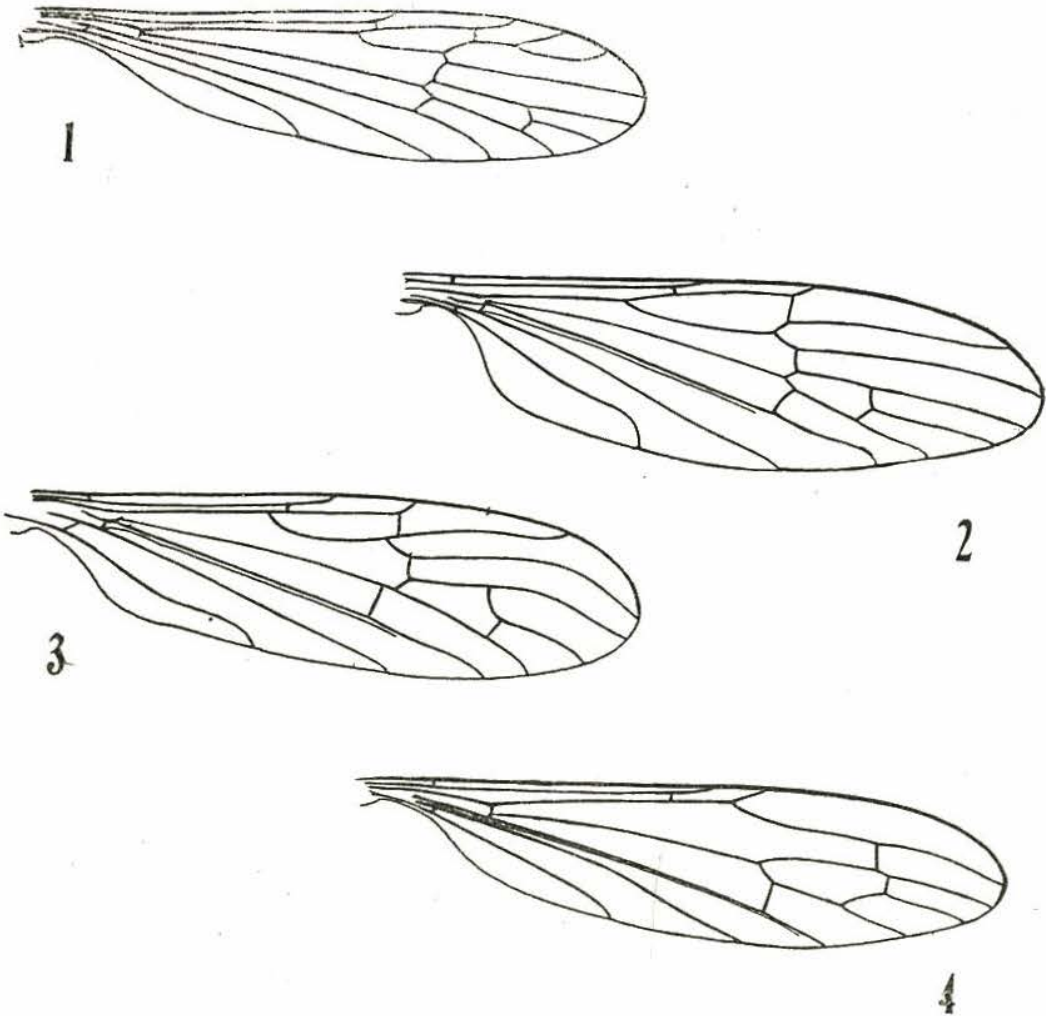

Explanation of figures.

1-Shannonnomyia hoffmani sp. n.; venation.

2-Teucholabis (Teucholobis) oteroi sp. n.; venation.

3-Teucholabis (Teucholobis) portoricana sp. n.; venation. 4-Toxorhina (Toxorhina) distalis sp. n.; venation. 